\title{
A Comparative study of Biodentine and Calcium Hydroxide as Pulpotomy Material in Primary Teeth.

\author{
Shamima Afroz ${ }^{1}$, Shiren sultana ${ }^{2}$, Nushrat saki ${ }^{3}$, Mohammad wahiduzzaman ${ }^{4}$, It.col.Md Abdul Hannan Sheikh ${ }^{5}$, Fahd a a karim ${ }^{6}$, Prof. Ali Asgor Moral ${ }^{7}$
}

\section{AFFILIATION:}

1. Shamima Afroz FCPS, Conservative Dentistry and Endodontics.

2. Shiren sultana FCPS, Conservative Dentistry and Endodontics, Assistant professor, Delta Medical College Dental Unit.

3. Nushrat saki MS, Conservative Dentistry and Endodontics . Assistant professor, Bangladesh Dental College.

4. Mohammad wahiduzzaman FCPS trainee, lecturer , Bangladesh Dental College

5. It.col.md abdul hannan sheikh FCPS,MCPS, DDS Classified specialized and head of the department Military Dental Centre, Dhaka cant.

6. Fahd A. A. karim FCPS, DDS Assistant professor, Update Dental College.

7. Prof. Ali Asgor Moral (BSMMU).

\section{Article info.}

Received: $2^{\text {nd }}$ Feb, 2018

Accepted: 13 May, 2018

Volume: 8, Issue-2 October, 2018

DOI: https://doi.org/10.3329/updcj.v9i1.41205

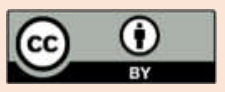

(C) Authors retain copyright and grant the journal right of first publication with the work simultaneously licensed under Creative Commons Attribution License CC - BY 4.0 that allows others to share the work with an acknowledgment of the work's authorship and initial publication in this journal.

https://creativecommons.org/licenses/by/4.0/

Publisher: Update Dental College, Dhaka, Bangladesh

Web: www.updatedentalcollege.edu.bd

E-mail: updcj@hotmail.com

$$
\begin{gathered}
\text { * Corresponding Author } \\
\text { Dr. Shamima Afroz } \\
\text { FCPS in Conservative Dentistry \& Endodontics, } \\
\text { Consultant, Aribah Dental Care } \\
\frac{\text { Email: S.shimu1421@gmail.com }}{\text { Phone-+880 1717241421 }}
\end{gathered}
$$

\section{Citation}

Shamima Afroz, Shiren sultana, Nushrat saki, Mohammad wahiduzzaman, It.col.Md Abdul Hannan Sheikh, Fahd a a karim, Prof. Ali Asgor Moral. A. Comparative study of Biodentine and Calcium Hydroxide as Pulpotomy Material in Primary Teeth. Update Dental College Journal. 2019 April; 9(1): 37-41 DOI: https://doi.org/10.3329/updcj.v9i1.41205

\begin{abstract}
Background: Pulpotomy is measured as one of the most worldwide accepted favourable clinical procedure for the treatment of deciduous tooth with reversible pulpitis with carious destruction of tooth tissue.

Objectives: To evaluate the clinical and radio-graphical findings of primary tooth with reversible pulpitis by Biodentine and Calcium Hydroxide as pulpotomy material.

Study Design: Randomized comparative study.

Study place and period: Conservative Dentistry \& endodontics department of Bangabandhu Sheikh Mujib Medical University, Dhaka, September 2013 to September 2014.

Study Population: The study population comprised of patients having primary tooth with reversible pulpitis irrespective of sex.

Methods/Procedure: According to inclusion and exclusion criteria, out of 100 primary teeth 50 teeth were treated with Biodentine (Group-A) and the remaining 50 teeth were treated with $\mathrm{Ca}(\mathrm{OH}) 2$ (Group-B). Clinical and radiographic follow up examination were done at 3months, 6 months and 12 months' interval to evaluate the rate of postoperative pain, swelling and periapical radiolucency. Statistical package for Social Science (SPSS) version 17 was used to analyze the collected data

Main outcomes measures (s): 01. Pain 02. Dentinal bridge 03. Root resorption

Results: At 3 months observation period, Biodentine and $\mathrm{Ca}(\mathrm{OH}) 2$ pulptomy of primary teeth showed $100 \%$ success rate in treating teeth with reversible pulpitis; neither pain nor swelling or radiographic sign of resorption was observed.

At 6 and 12 months following the completion of treatment except in two case in group $A$ and four case in group $B$ in observation period, there results were similar to that of 3 months. Two Biodentine $(4 \%)$ and four $\mathrm{Ca}(\mathrm{OH}) 2(8 \%)$ therapy reported pain, swelling. There was no statistical difference between the two group ( $p>0.05$ ).

Conclusion: So, we can say that clinical and radiographic end result of Biodentine is better than $\mathrm{Ca}(\mathrm{OH})_{2}$ as a pulpotomy material in mature primary tooth with reversible pulpitis.
\end{abstract}

\section{KEY WORDS:}

\section{Dental Education, Teacher's Evaluation}

\section{Background}

For maintaining the real shape of the arch and chewing function, it is essential to preserve deciduous teeth before the eruption of permanent teeth. Primary teeth plays a vital role to prevent damaging tongue and speech habit, preserve aesthetics, and maintain chewing activity. Before extraction of deciduous teeth, it should ideally be restored if possible ${ }^{1}$.

If carious process exposes the pulp, then the tissue becomes inflamed. ${ }^{2}$ Now Pulpotomy is a choice of treatment for preserving primary teeth. There is no involvement of the radicular pulp. Pulpotomy is a vital pulp therapy in which a portion of vital coronal pulp tissue is removed surgically and the remaining redicular dental pulp is covered with a suitable material that protects the pulp from further injury and permits and promotes healing ${ }^{3}$. Formocresol, ferric sulphate, calcium hydroxide, Mineral trioxide aggregate (MTA), Portland cement 
(PC) etc are used as a medicaments into the radicular tissue. Widely used Calcium hydroxide $[\mathrm{Ca}(\mathrm{OH}) 2]$ has been a popular pulpotomy material for vital pulp therapy. It was announced by Herman as a biologic dressing. ${ }^{4}$ although its apparent success in vital pulp therapy, considerable confusion and condemnation of this material have long persisted because $\mathrm{Ca}(\mathrm{OH}) 2$, in the pure state and in the original formulations, actually kills a certain amount of tissue when placed in direct contact with the pulp rather than merely functioning as a biologic dressing. Because of its alkalinity ( $\mathrm{pH}$ of 12 ), it is so caustic that when placed in contact with vital pulp tissue, the end result is a superficial necrosis of the pulp. ${ }^{5}$ Different studies have shown that $\mathrm{Ca}(\mathrm{OH}) 2$ is extremely toxic to cells in tissue culture, it has also some tissue changing and dissolving effects. ${ }^{6-8}$ The usage of Calcium hydroxide is not routinely recommended for primary dentition because its application frequently results in the development of chronic pulpal inflammation and internal root resorption. ${ }^{9-1}$

For stimulating continued dentin formation and apical closure of immature teeth more biocomtible materials and procedures are in search.

An effective dental material in conventional pulp therapy, Biodentine is considered as newcomer.

Depend on "Active Biosilicate Technology" it is a calcium silicate cement and composed of powder and liquid form. The powder portion consist of Tri-calcium silicate and main core material, Di-calcium silicate as second core material, Calcium carbonate and oxide as fillers, Iron oxides as shade and Zirconium oxide as radiopeacifier. The liquid portion consists of Calcium chloride as accelerator and hydrosoluable polymer as water reducing agents ${ }^{15}$.

The Effective applications of Biodentine on pulp therapy have already been explored by a number of investigators. Animal histological studies have showed that no sign of pulp cell damage could be identified after placing Biodentine into animal and human pulp as pulp capping material. Furthermore, Biodentine stimulates the expression of collagen, dentine sialoprotein and osteonectine ${ }^{16}$ involved in mineralization in cultured human pulp cells. The antibacterial effects of Biodentine have also been studied. These studies have indicated that although Biodentine decreases inhibition against Salmonella typhimurium and E.coli. However, its antibacterial effect is comparable to MTA and biocompatible to human pulp cells when used as pulp capping materials.

Combining scientific information, human health \& social value it is logical to consider Biodentine as a sound material for pulpotomy in primary teeth.

\section{Materials \& methods}

Study Design: Randomized comparative study.

Study Period: September 2013 to September 2014.

Place of study: This study was conducted in Faculty of Dentistry, Department of Conservative Dentistry \& Endodontics, Bangabandhu Sheikh Mujib Medical University, Dhaka-1000, Bangladesh.

Study Population: The study population was comprised of patients having mature primary tooth with reversible pulpitis irrespective of sex and tooth number.
Sampling method: Random sampling technique was employed to select the case.

Main outcome variable: 01 . Pain, 02. Dentinal bridge, 03. Root resorption

Sample size: To determine the sample size the following formula was followed

$$
\mathrm{z}^{2} \mathrm{pq}
$$

$\mathrm{N}=$

$d^{2}$

$=98.4$

100 patients with reversible pulpitis were selected for the study. They were randomly divided into two groups: Group=A contains fifty patients having mature primary tooth with reversible pulpitis treated by Biodentine. Group-B contains fifty patients having mature primary teeth with reversible pulpitis treated by $\mathrm{Ca}(\mathrm{OH})_{2}$.

Inclusion criteria: 01 . Carious exposure of pulp in vital primary mature molar teeth.

\section{Age: 6 - 9 years}

Exclusion criteria: 01. Mechanical exposure of pulp. Un restorable teeth.

04. Immature tooth

03. Previously treated or restored teeth.

\section{Procedure of preparation and organizing materials:}

Study procedure: A total of 100 teeth that fulfilled the inclusion criteria were selected for the study after clinical and radio-graphical evaluation. The occupation, socio-economic condition, general health status, drug history and past dental history of the patients, spontaneous pain or pain during the night were be obtained by face to face interview and was recorded in prefixed questionnaire by parent. Percussion and pulp sensitivity tests was performed and radiographs was taken to assess pulpal health.

\section{STUDY TOOTH PREPARATION:}

Step- I:

- Disinfection of the operative field and proper sterilization of instruments were ensured.

- Hand gloves, face mask was used in every case in an aseptic manner.

- Local anesthesia was administered.

- Isolation of teeth was done with rubber dam and with the use of saliva ejector.

Step - II: Firstly, all caries was removed by using No.\#4 round bur in a high- speed hand piece using copious water spray.

Step-III: Coronal pulp from pulp chamber was removed by using sterile excavator or round bur until the orifices of canal are seen. Finally, the pulp chamber was rinsed with normal saline and the orifices was covered with a small cotton pellet soaked in normal saline with pressure until bleeding was controlled. 


\section{Step-IV: Patients in Group A:}

The following procedure was followed:- Biodentine Cement was mixed according to manufacturer instruction and applied over the amputed pulp to cover the full depth of the prepared cavity. Then, by using a sterile cotton pellet cement was condensed properly over the chamber. Bite was checked for any high spot. Then, Post-operative radiograph was taken.

\section{Patients in Group B:}

The following procedure was followed:- calcium hydroxide powder was mixed with saline to a thick consistency. The paste was carefully placed on the pulp stump surface 1 to $2 \mathrm{~mm}$ thick. The pulp chamber was filled respectively with a reinforced $2 \mathrm{~mm}$ thick layer of zinc oxide eugenol paste and Glass ionomer (Fuji-IX) cement and a coat of varnish was applied. Post operative radiograph was taken and recalled on next day.

Follow up: The children were recalled for clinical and radiographic evaluations after 3,6 and 12 months' interval for the assessment of dentinal bridge formation \& root resorption.

Procedure of collecting data: A clinical checklist was use to record the data.

Procedure of data analysis: Collected data was analyzed using statistical Package for Social Science (SPSS) version 17.

Quality assurance strategy: Maximum quality was assured by using disposable and sterilized instruments.

\section{Result:}

Table 3.1 Distribution of study patients according to teeth number $(n=100)$

\begin{tabular}{|l|c|c|c|c|}
\hline \multicolumn{1}{|c|}{ Teeth Number } & $\begin{array}{c}\text { Group-I } \\
\text { (n=50) }\end{array}$ & & $\begin{array}{c}\text { Group-II } \\
\text { (n=50) }\end{array}$ & \\
\hline \multicolumn{1}{|c|}{ Location } & No. & (\%) & No. & (\%) \\
\hline Right upper 1st molar & 6 & 12.0 & 6 & 12.0 \\
\hline Right upper 2nd molar & 8 & 16.0 & 8 & 16.0 \\
\hline Right lower1st molar & 4 & 8.0 & 6 & 12.0 \\
\hline Right lower 2nd molar & 2 & 4.0 & 10 & 20.0 \\
\hline Left upper 1st molar & 8 & 16.0 & 4 & 8.0 \\
\hline Left upper 2nd molar & 8 & 16.0 & 6 & 12.0 \\
\hline Left lower1st molar & 8 & 16.0 & 8 & 16.0 \\
\hline Left lower 2nd molar & 6 & 12.0 & 2 & 4.0 \\
\hline \multicolumn{1}{|c|}{ Molar (Total) } & \multicolumn{4}{|l|}{} \\
\hline Mandibular first molar & 12 & 24.0 & 14 & 28.0 \\
\hline $\begin{array}{l}\text { Mandibular second } \\
\text { molar }\end{array}$ & 8 & 16.0 & 14 & 28.0 \\
\hline Maxillary first molar & 14 & 28.0 & 8 & 16.0 \\
\hline Maxillary second molar & 16 & 32.0 & 14 & 28.0 \\
\hline
\end{tabular}

Group I= Boidentine, Group II= Calcium hydroxide

Table 3.1 showed the distribution of the study teeth, it was observed that Mandibular first molar was found $12(24.0 \%)$ in group I and $14(28.0 \%)$ in group II. Mandibular second molar was found $8(16.0 \%)$ in group I and $14(28.0 \%)$ in group II. Maxillary first molar was found $14(28.0 \%)$ in group I and $8(16.0 \%)$ in group II. Maxillary second molar was found $16(32.0 \%)$ in group I and $14(28.0 \%)$ in group II.
Table 3.2 Clinical assessment of post operative pain in evaluation period $(n=100)$

\begin{tabular}{|c|c|c|c|c|c|}
\hline $\begin{array}{l}\text { Pain status } \\
\text { (VAS score) }\end{array}$ & $\begin{array}{l}\text { Group-I } \\
(n=50)\end{array}$ & & $\begin{array}{c}\text { Group-II } \\
(n=50)\end{array}$ & & $P$ value \\
\hline & No. & (\%) & No. & (\%) & \\
\hline \multicolumn{6}{|c|}{ Preoperative } \\
\hline Present & 50 & 100 & 50 & 100 & \\
\hline Absent & 00 & 00 & 00 & 00 & \\
\hline \multicolumn{6}{|c|}{$\begin{array}{l}\text { First follow up } \\
\text { (3 months) }\end{array}$} \\
\hline Present & 0 & 00 & 0 & 00 & \\
\hline Absent & 50 & 100 & 50 & 100 & \\
\hline \multicolumn{6}{|l|}{$\begin{array}{l}\text { Second follow } \\
\text { up ( } 6 \text { months) }\end{array}$} \\
\hline Present & 2 & 4 & 4 & 8 & \\
\hline Absent & 48 & 96 & 46 & 92 & $0.338^{\mathrm{ns}}$ \\
\hline \multicolumn{6}{|c|}{$\begin{array}{l}\text { Third follow up } \\
\text { (12 months) }\end{array}$} \\
\hline Present & 2 & 4 & 4 & 8 & \\
\hline Absent & 46 & 92 & 42 & 84 & $0.318^{\mathrm{ns}}$ \\
\hline
\end{tabular}

ns= not significant , $\mathrm{P}$ value reached from fisher exact test.

Table 3.2 shows the pain status of the study teeth during third follow up and observed that, pain was not found in both groups at 1st follow-up. Second follow up pain was found $2(4.0 \%)$ cases in group I and $4(8.0 \%)$ cases in group II. Third follow up pain was found $2(4.0 \%)$ cases in group I and $4(8.0 \%)$ cases in group II. Due to pain, six cases dropped out from third follow up, among them two cases in group I and four cases in group II. The difference was not statistically significant ( $p>0.05$ ) between two groups.

Figure 1: Bar diagram showing clinical assessment of postoperative pain in evaluation period

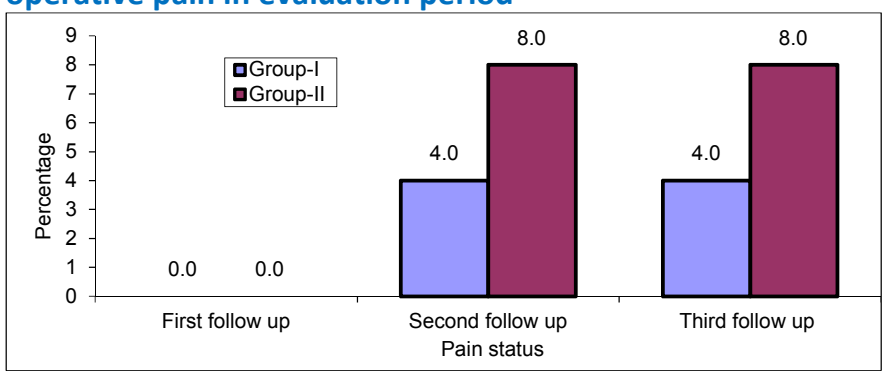

This bar diagram showed clinical assessment of post operative pain in evaluation period

Table 3.3 Radiological assessment of dentinal bridge of the groups at evaluation period $(n=100)$

\begin{tabular}{|c|c|c|c|c|c|}
\hline $\begin{array}{l}\text { Dentinal } \\
\text { bridge }\end{array}$ & $\begin{array}{c}\text { Group-I } \\
(\mathrm{n}=50)\end{array}$ & & $\begin{array}{c}\text { Group-II } \\
(\mathrm{n}=50)\end{array}$ & & P value \\
\hline & No. & $(\%)$ & No. & (\%) & \\
\hline \multicolumn{6}{|l|}{$\begin{array}{l}\text { Preoperative } \\
\end{array}$} \\
\hline Present & 00 & 0.0 & 00 & 0.0 & \\
\hline Absent & 50 & 100 & 50 & 100 & \\
\hline \multicolumn{6}{|l|}{$\begin{array}{l}\text { First follow up } \\
\text { (3 months) }\end{array}$} \\
\hline Present & 0 & 0.0 & 0 & 0.0 & \\
\hline Absent & 50 & 100 & 50 & 100 & \\
\hline \multicolumn{6}{|l|}{$\begin{array}{c}\text { Second follow } \\
\text { up } \\
\text { (6 months) }\end{array}$} \\
\hline Present & 20 & 40 & 14 & 28 & \\
\hline Absent & 30 & 60 & 36 & 72 & ${ }^{\mathrm{a}} 0.205^{\mathrm{ns}}$ \\
\hline \multicolumn{6}{|l|}{$\begin{array}{l}\text { Third follow } \\
\text { up (12 months) }\end{array}$} \\
\hline Present & 46 & 92 & 38 & 76 & \\
\hline Absent & 4 & 8 & 12 & 24 & ${ }^{\mathrm{b}} 0.029^{\mathrm{s}}$ \\
\hline
\end{tabular}

${ }^{a} \mathrm{P}$ value reached from chi square test. ${ }^{\mathrm{b}} \mathrm{P}$ value reached from fisher exact test. 
Table 3.3 shows the dentinal bridge of the study teeth during third follow up and observed that, dentinal bridge was not found in both groups at 1st followup. Second follow up dentinal bridge was found $20(40.0 \%)$ cases in group I and $14(28.0 \%)$ in group II. Third follow up dentinal bridge was found $46(92.0 \%)$ cases in group I and $38(76.0 \%)$ in group II. Third follow up dentinal bridge was statistically significant $(p<0.05)$ between two groups.

Table 3.4 Radiological assessment of root resorption of the groups at evaluation period $(n=100)$

\begin{tabular}{|c|c|c|c|c|c|}
\hline Root resorption & $\begin{array}{c}\text { Group-I } \\
(n=50)\end{array}$ & & $\begin{array}{l}\text { Group-II } \\
(\mathbf{n}=\mathbf{5 0})\end{array}$ & & P value \\
\hline & No. & $(\%)$ & No. & $(\%)$ & \\
\hline \multicolumn{6}{|l|}{ Preoperative } \\
\hline Present & 00 & 0.0 & 00 & 0.0 & - \\
\hline Absent & 50 & 100 & 00 & 100 & \\
\hline \multicolumn{6}{|l|}{$\begin{array}{c}\text { First follow up } \\
\text { (3 months) }\end{array}$} \\
\hline Present & 0 & 00 & 0 & 00 & - \\
\hline Absent & 50 & 100 & 50 & 100 & \\
\hline \multicolumn{6}{|l|}{$\begin{array}{l}\text { Second follow up } \\
\text { (6 months) }\end{array}$} \\
\hline Present & 0 & 00 & 0 & 00 & - \\
\hline Absent & 50 & 100 & 50 & 100 & \\
\hline \multicolumn{6}{|l|}{$\begin{array}{l}\text { Third follow up } \\
\text { (12 months) }\end{array}$} \\
\hline Present & 0 & 00 & 0 & 00 & - \\
\hline Absent & 50 & 100 & 50 & 100 & \\
\hline
\end{tabular}

Table 3.4 shows the root resorption of the study teeth during third follow up and observed that, root resorption was not found in both groups at preoperative, 1st follow-up, second follow up and 3rd follow up.

Table 3.5 Final outcome treatment of the study patients $(n=100)$

\begin{tabular}{|c|c|c|c|c|c|}
\hline Site & $\begin{array}{c}\text { Group-I } \\
(\mathbf{n}=\mathbf{5 0})\end{array}$ & & $\begin{array}{c}\text { Group-II } \\
(\mathbf{n}=\mathbf{5 0})\end{array}$ & & P value \\
\hline & No. & $\mathbf{( \% )}$ & No. & $\mathbf{( \% )}$ & \\
\hline Success & 46 & 92.0 & 42 & 84.0 & $0.218^{\text {ns }}$ \\
\hline Failure & 4 & 8.0 & 8 & 16 & \\
\hline
\end{tabular}

ns= Not significant

$P$ value reached from fisher exact test

Table 3.5 showed the final outcome of treatment of the study patients. It was observed that $46(92.0 \%$ ) was success (no pain plus vital teeth plus no resorption plus dentin bridge) in group I and $42(84.0 \%)$ group II. Four $(8.0 \%)$ was failure in group I and $8(16.0 \%)$ in group II. The difference was not statistically significant $(\mathrm{p}>0.05)$

\section{Discussion:}

Previous study have indicated that pulpotomy is effective for the treatment of carious or mechanical exposure in primary teeth. ${ }^{17,} 18$ Due to its high success rate, it is an acceptable clinical technique for treating inflamed coronal pulp. Treatment usually consist of coronal pulp followed by application of medicaments such as Biodentine, MTA, Portland Cement, Formocresol, Calcium Hydroxide, Ferric Sulphate, Gluteraldehyde and the final restoration. ${ }^{17}$

In the present study, 50 primary teeth were treated by Biodentine (Group-A) and the remaining 50 primary teeth were subjected to $\mathrm{Ca}(\mathrm{OH})_{2}$ (Group-B). All the cases in both groups examined clinically and radiologically at 3,6, and 12 months interval. The followings are the discussion regarding the result found in the present study.

The result of the present study showed that regarding pulpotomy with biodentine, all cases showed successful at 3 , 6 , and 12 months following treatment but two patient reported spontaneous pain at 12 months. When these teeth 40 | P a g e were further investigated by pulp vitality test, teeth were response positively. Only in two case (4\%), moderated pain was found along with no response in pulp vitality test. The teeth were treated by pulpectomy and pain was subsided. The result found that the present study was corresponded to Walton et $\mathrm{al}^{19}$. $100 \%$ success rate was achieved in Biodentine in respect of pain of these studies.

Regarding the dentine bridge formation, the results of the present study revealed that in group-A, dentine bridge was evident in 46 of 50 (92\%) cases in 12 months following treatment with Biodentine. The results were corresponding to previous study of Rood. These studies have indicated that in the teeth treated with Biodentine, the beginning of mineralized deposition could be radiographically detected in all $(100 \%)$ cases and complete tubular dentine bridge was formed in $84.6 \%$ cases.

However, the time required for hard tissue barrier is different between the present studies with of previous studies. In the present study, 20 cases $(40 \%)$ of group=A revealed that initiation of hard tissue barrier was recognized at 6 months. Similarly, in group-B cases of $\mathrm{Ca}(\mathrm{OH})_{2}$ treated teeth showed hard tissue barrier was observed after 12 months. However, it has been claimed that minimum time required for the induced hard tissue barrier formation needs at least 6 weeks according to ES Barr. ${ }^{1}$

The reason of dentine bridge formation by MTA and Bidentine is not clearly understood. In the present study. However, according to previous study, it can be considered that formation of dentine bridge may be due to their excellent setting ability and fast setting time (about 20 minutes), avoiding diffusion of materials into the tissue, micro leakage thorough out the entire procedure.

Regarding assessment of root resorption (internal \& external) following therapy, in group-A \& group- B none of 50 cases showed resorption throughout the total follow up period. The results of the present study confirmed the hypothesis that Biodentine pulpotomy have high success rate than $\mathrm{Ca}(\mathrm{OH})_{2}$ as pulpotomy materials. All thought a few study have been performed regarding this matter. It can be considering that Biodentine can also be used successfully as pulpotomy material. Further research is necessary with long term clinical evaluation and a larger sample size to confirm the results.

Conclusion: It can be concluded that the clinical and radiological outcome of Biodentine is better than $\mathrm{Ca}(\mathrm{OH})_{2}$ as pulpotomy agents in mature primary tooth with reversible pulpitis.

\section{Acknowledgement:}

I wish to acknowledge Dr. Dillruba Rahman, Assistant Professor, Dept. of Dental Public Health, Update Dental College \& Hospital for contributing article preparation from my thesis paper. I am eternally grateful to her effort for the evolution of the initial draft of this article to present state. 


\section{References:}

1.Barr ES Flaitz CM, Hicks MJ 1991, ' A retrospective radiographic evaluation of primary molar pulpectomies' Pediatric Dentistry, vol.13 pp.4-9. PMid:1945984

2.Eidelman E, Holan G, Fucks AB 2001 ' Mineral Trioxide Aggregate VS Formocresol In pulpotomized primary molars a preliminary report' Pediatric Dentistry, vol.23 pp.15-18. PMid:11242724

3.Bakland LK 2002 'Endodontic considerations in dental trauma. In: Ingle JI, Bakland LK, eds. Endodontics. Toronto: BC Decker Inc, pp795-844.

4. Herman B. Biologische Wurzelbehandlung, Frankfurt, Germany, 1936, W. Kramer.

5. McDonald RE, Avery DR, Dean JA. Dentistry for the child and adolescent, ed 8 , St.Louis, Mosby Co, 2004. Treatment of deep caries, vital pulp exposure and pulpless teeth. 389-412.

6. Anusavice KJ. Phillip's science of dental materials, ed 10, Philadelphia, WB Saunders, 1996. Biocompatibility of dental materials. 57-110.

7. Andersen M, Lund A, Andreasen JO, Andreasen FM. In vitro solubility of human pulp tissue in calcium hydroxide and sodium hypochlorite. Endod Dent Traumatol 1992;8:104-108.

https://doi.org/10.1111/j.1600-9657.1992.tb00445.x PMid:1289067

8. Barnes IE, Kidd EA. Disappearing Dycal. Br Dent J 1979;147:111. https://doi.org/10.1038/sj.bdj.4804296

9. Law DB. An evaluation of vital pulpotomy technique. J Dent Child 1956;23:40-4.

10. Magnusson B. Therapeutic pulpotomy in primary molars - Clinical and histological follow-up. I. calcium hydroxide paste as a wound dressing. Odoentol Revy 1970; 21:415-31. PMid:5276723

11. Schroder U.A 2 -year follow-up of primary molars. Pulpotomized with a gentle technique and capped with calcium hydroxide. Scand J Dent res 1978;86:273-8. https://doi.org/10.1111/j.1600-0722.1978.tb00628.x

12. Avram CA, pulver F. Pulpotomy medicament for vital primary teeth. J Dent child 1989;56:426-34. PMid:2530256

13. Camp J. Pediatric Endodontics: Endodontic treatment for the primary and young permanent dentition. In: Cohen S, Burns RC, editors. Pathways of the pulp. 8th ed. St. Louis: Mosbg year Book;2002.P.880-4.

14. Rood H, waterhaouse P, Fuks A, Fayle S, Moffat M. Pulp therapy for primary molars. Int J Paediatr Dent 2006: 16(suppl 1); S15-23.

https://doi.org/10.1111/j.1365-263X.2006.00774.x PMid:16939452

15. Scientific file of biodentine.

16. Aeinchchi M. Eslami, B, Ghanbariha, M., Saffar, As., 3003. Mineral trioxide aggregate (MTA) and calcium hydroxide as pulp-capping agents in human teeth; a preliminary report, Int, Endo, J., vol.36,pp.225-231.

17. Bakland, LK, 2000. Management of traumatically injured pulps in immature teeth using MTA J Calif Dent Assoc, vol,28 pp.855-8. PMid:11811234

18. Pitt Fort T.R. et al., 1996. Using mineral trioxide aggregate as pulp-capping material J Am Dent Assoc., vol,127,pp,1491-1494

19. Walton, RE, Torabinefad M., 2002. Management of incompletely formed roots. In: Principles and Practice of Endodontics. 3rd ed. Philadelphia, Pa: WB Saunders: pp,388-404. 